\section{Trust in medicine}

\author{
Joseph A. Cook
}

Physic and Philanthropy: A History of the Wellcome Trust 1936-1986. By A. Rupert Hall and B.A. Bembridge. Cambridge University Press: 1986. Pp.479. £25, $\$ 39.50$.

IN 1880, Henry Wellcome and Silas Burroughs formed a partnership to introduce the American practice of wholesale manufacturing of ready-made compressed pills, called "Tabloids", into Britain. The company's early success was due largely to showmanship and sales of "non-ethical" products such as cod liver oil with malt extract. However, Henry Wellcome, the sole owner after Burroughs's death in 1895 , developed great respect for medical research and sought to exploit the opportunities it offered for his business. As the puritanical son of a missionary, Wellcome was also ever mindful of a wish, expressed at age 21 , "to live a life devoted to the true God and to mankind". Combining this desire with that of ensuring the continued success of his company, on his death in 1936 he left the entire business to his Trust; profits were to be invested in medical research for the public benefit.

Physic and Philanthropy is a history marking the fiftieth anniversary of the Wellcome Trust, the largest philanthropic organization concerned with medical research in Britain. There is much to celebrate, although the first Trustees may not have thought so during the early years. Indeed, the Nobel laureate and chairman of the Board of the Trust from 1938 to 1960 , Sir Henry Hallett Dale, is quoted as making some unflattering remarks about the Trust's benefactor and his interest in archaeology, medical history and the collection of artefacts which now rests in the Science Museum as the Wellcome Museum of the History of Medicine. The first 15 years of the Trust were occupied by keeping the business afloat during difficult times, arranging for the disposition of archaeological remains - but giving away only modest sums for the purposes of medical research.

A. Rupert Hall, a historian of science, has written the bulk of the book. The second, smaller part, which describes the support provided in various areas of interest to the Trust, is contributed by B.A. Bembridge, an assistant director of the Trust since 1969. Perhaps it is just as well that there was little to distribute in the early years, for there was no clear policy from the Trustees as to what ought to be supported. As Hall notes, "no one could describe [their research policy] as highly imaginative, and its innovative fruits were at best indirect." The Trust's grants were heavily weighted to buildings and equip-
Kondi in East Africa in the 1930s and 1940 s to the more recent studies by David Warrell on the pathophysiology of cerebral malaria in Thailand. Support by the Trust for clinical sciences, buildings, equipment and basic sciences is also well documented.

Sometimes the details of the Trustees' actions become tedious. But it is important to the history of the Trust that the Trustees wrestled early with the problem of how to obtain more capital for the business (the Wellcome Foundation) and also to diversify the Trust's source of income. Both could be accomplished by selling shares to the public. Trustees first considered this solution in the early $1960 \mathrm{~s}$ but only finally acted on it in 1986. Part of the delay revolved around whether this violated the spirit if not the letter of Henry Wellcome's will. In any case, 25 per cent of the business is now held by the public through shares in the holding company, Wellcome plc. The Trust received $£ 200$ million from the sale, which protects it from sudden down turns in the pharmaceutical industry. The move also makes nationalization (a greater concern in the 1960s) less likely.

The Trust's spending reached $£ 35$ million in the two years ending in 1984 . With the sale of stock and, more recently, the licensing of azidothymidine (AZT) for the treatment of AIDS, its budget is likely to increase. It is expected that the Trust will have available a sum approximately equal to that expended annually by the British Medical Research Council, emphasizing the importance of Wellcome to medical research in Britain. (Readers in the United States will recognize the Trust as the source of the BurroughsWellcome Fund, a more homeopathic dose of Wellcome philanthropy. The Fund was created in 1955 when Sir Henry Dale and the president of the American subsidiary, William Creasy, decided to take advantage of the US tax laws allowing industries to establish charitable funds from money that would otherwise go to the Internal Revenue Service.)

Active scientists in Britain will be interested in this careful documentation of Wellcome's enviable record. But more than as a guide to current grant-seekers, the book shows how and why some of the major medical research projects of the past 50 years were supported, and how the Wellcome Trust became a powerful force in science and medical research - a realization of Henry Wellcome's wish to serve mankind. Following a difficult beginning the Trust ends its first 50 years on a high note indeed; one hopes that the next 50 will be equally successful.

Joseph A. Cook is Director of the Program in Tropical Disease Research, The Edna McConnell Clark Foundation, 250 Park Avenue, New York, New York 10017, USA. 